\title{
Dynamics of land use
}

\section{and land cover in a Mexican national park}

\section{Dinámica de uso y cobertura del suelo en un parque nacional mexicano}

\author{
María del Rosario Pineda-López', Ernesto Ruelas Inzunzal*, Lázaro R. Sánchez-Velásquezl, \\ Marco A. Espinoza Guzmán², Alberto Rojo Alboreca ${ }^{3}$ and Suria G. Vásquez-Morales ${ }^{4}$
}

1 Universidad Veracruzana. Instituto de Biotecnología y Ecología Aplicada. Xalapa, Veracruz, México.

2 Universidad Veracruzana. Facultad de Biología. Xalapa, Veracruz, México.

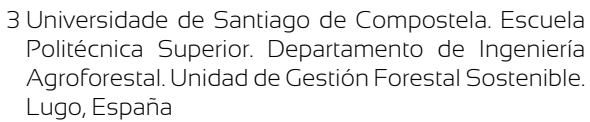

3 Universidade de Santiago de Compostela. Escuela Politécnica Superior. Departamento de Ingeniería Agroforestal. Unidad de Gestión Forestal Sostenible. Lugo, España

4 El Colegio de la Frontera Sur. Departamento de Con-
servación de la Biodiversidad. México

* Corresponding author: ruelas.uv@gmail.com

\section{RESUMEN}

Para entender la dinámica de la cobertura del suelo en el Parque Nacional Cofre de Perote, se hizo una comparación de las tasas de cambio de uso a dos escalas durante el periodo 1995-2004. A escala meso, se estudiaron estos patrones en toda la superficie del Parque Nacional Cofre de Perote, que es una de las 60 montañas prioritarias de México y también una importante área natural protegida del país ubicada en el estado de Veracruz. A escala micro el estudio se enfocó en el ejido El Conejo que se encuentra dentro de los límites de este parque nacional. Se utilizaron ortofotos digitales del gobierno federal para determinar el cambio en nueve categorías de uso del suelo. En ambas, meso y microescalas, se encontró que las categorías predominantes de cobertura son la agricultura y el bosque. Las probabilidades de cambio de cobertura del suelo en ambas escalas son bajas y tienen valores esencialmente iguales para la mayoría de las categorías de uso, reflejando tanto pequeñas ganancias en cobertura forestal en todo el parque como la efectividad del ejido en el manejo de recursos naturales dentro del parque. Se considera que los hallazgos de este estudio pueden ser aplicables a la situación prevaleciente en los restantes parques nacionales de México; al final se discute la importancia de integrar a los actores locales en el manejo de áreas naturales protegidas.

Palabras Clave: cartografía, ejido El Conejo, matriz de transición, ortofotos digitales, Parque Nacional Cofre de Perote, uso del suelo.

\section{ABSTRACT}

To understand the dynamics of land cover at the Parque Nacional Cofre de Perote, the rates of change in land use were compared at two different scales during the period 1995-2004. At the meso scale, these patterns were studied throughout the entire Parque Nacional Cofre de Perote, which is one of the 60 priority mountains of Mexico, and an important natural protected area of the country located in the state of Veracruz. At a micro scale, the work was focused in ejido El Conejo, located within the boundaries of this national park. Federal government digital orthophotos were used to determine changes in nine categories of land use. In both, the meso- and micro-scale, it was found that the predominant land cover categories are agriculture and forest. The probabilities of land cover change at both scales are low and essentially the same for most land use categories, reflecting both small gains in forest cover park-wide as well as the effectiveness of the ejido in managing natural resources within the park. The authors consider that the findings of the study may be applicable to the broader situation of national parks in Mexico and, finally, the importance of integrating local stakeholders in the management of natural protected areas is discussed.

Keywords: cartography, digital orthophotos, ejido El Conejo, land use, Parque Nacional Cofre de Perote, transition matrix. 


\section{INTRODUCTION}

The drivers of deforestation worldwide are broad and complex, and involve many institutional, technological, socioeconomic and demographic factors (Hobbs, 1993; Lee, Carr and Lankerani, 1995; Collinge, 1996; Ghosh, 2004; Tabarelli, Cardoso da Silva and Gascon, 2004). Locally, some practices that have contributed to the loss of the world's forests are itinerant agriculture, slash-andburn agriculture, opening of clearings to colonize forested areas, illegal logging, man-made forest fires (that have contributed to net forest losses in temperate and tropical forests alike) and other modifications to land use (Consejo Civil Mexicano para la Silvicultura Sostenible [CCMSS], 2009).

Understanding the dynamics of land use and land cover is the key to address problems and changes at any scale (Geist and Lambin, 2001). Land use, land cover and forestry investigations (LULCF) evaluate these landscape transformations and enable researchers to identify its causes and consequences, and represent a valued tool for users of these forests and for planners of public policies concerned with land use. LULCF studies can generate forecasts and project future scenarios in both the natural and the social environment, and help to estimate economic outcomes (Ellis and Pontius, 2007).

The country-scale panorama is dire. Mexico has lost most of its tropical lowland and mid-elevation temperate forests. This loss continues to advance at a rate close to $1.1 \%$ per year (Organisation for Economic Co-operation and Development [OECD], 2003; Food and Agriculture Organization of the United Nations [FAO], 2016), and strategies focused on conserving the remaining fragments and restoring degraded forests are needed. According to Lambin (1997), quantitative reference data to guide where, when, how much, and why landscape modifications occur, are key to the success of forest management but very often incomplete.

Studies of land use change in Mexico are a key priority because it is one of the countries with the highest deforestation rates (Bocco, Mendoza and Masera, 2001). The country lost 720000 ha of forests and semi-arid veg- etation per year during the nineties, the period in which we initiated this study. Patterns of deforestation differ by region, and almost $80 \%$ of it occur in the central and southern portions of this country (Masera, 1996). It is important to highlight that forest degradation, the loss of structural elements of forests, and decays in the quality of ecosystem services are serious processes whose extent is currently unknown but that can be added to the problem of forest loss.

Land use in Mexico's state of Veracruz has been historically intense and has resulted in present-day fragmented forest landscapes. The forested surface of the state has been reduced to approximately $18 \%$, while cattle pastures occupy $47 \%$, agriculture $28 \%$, and the remaining area is composed of semi-arid habitats and wetlands (Secretaría de Desarrollo Agropecuario, Rural y Pesca del Estado de Veracruz [Sedarpa] and Comisión Nacional Forestal [Conafor], 2006; Gerez and Pineda-López, 2011). Statistics from most natural protected areas in the state are similar state-level ones.

\section{OBJETIVES}

The purpose of this work was to present an analysis of land use and land cover at two different scales inside a national park and to describe its trends over a decade (1995-2004).

The meso-scale analysis took place at the Parque Nacional Cofre de Perote (PNCP), one of Mexico's oldest national parks, and at a micro-scale at the ejido ${ }^{1} \mathrm{El}$ Conejo, a titled community nested inside the boundaries of the PNCP. Given the trends detected at both scales, the probability of change in land cover was estimated and related to land tenure; also, forecasts of future scenarios for all land cover categories are presented. In the end of the study, specific recommendations for the management of the park and for augmenting its forest area are presented.

\footnotetext{
1 Ejido: Mexican ejidos are the result of the Agrarian Reform of 1930-1960, after the Mexican Revolution. The ejido is a land tenure regime apportioned by the federal government, in which a large plot of land is granted to an assembly of families. Ejidos have areas designated for communal use, primarily for forestry and plots for individual, primarily agricultural, use.
} 


\section{MATERIALS AND METHODS}

The study is focused on two scales, a 'meso-scale' ( $>10^{4}$ ha) and 'micro-scale' ( $\left.<10^{3} \mathrm{ha}\right)$, with a difference of about one order of magnitude.

\section{The meso-scale: land use and land cover at the Parque Nacional Cofre de Perote}

Decreed in 1937, the PNCP has an area of approximately 11700 ha. It was established with the aim of protecting conifer forests (importantly sacred fir, Abies religiosa) around the highest peak of a volcano (Fig. 1). Different land use and vegetation type categories were identified based on an analysis of digital orthophotos at a 1:20 000 scale at two different points in time, 1995 and 2004. For latitude, orthophoto line E and for longitude zone 14 were used in quadrants E14B26, E14B27, E14B36 and E14B37 of federal government coverage (Instituto Nacional de Estadística, Geografía e Informática [Inegi], 1995a, 2004a). This resolution was elected because it offers optimal results at this and lower grain resolutions (González and Marey, 2009).

The classifications of land use and vegetation are based on size, shape, shading, tone and texture of the objects in these images (Graham and Read, 1990) and are organized in the following categories based on ground-truthing: forest, agriculture, human settlements, open woodlands, open woodlands with agriculture, open woodlands with montane grassland, montane grassland (zacatonal), water body and without vegetation.

Ground-truthing of features observed in orthophotos were made by plotting 1-ha parcels throughout the study area using ArcInfo's extension 'Repeating Shapes' and placing them in randomly selected points totaling $10 \%$ of the PNCP area using the extension 'Random Point Generator v. 1.1' (Environmental Systems Research Institute, Inc. [ESRI], 1999). For ground truthing, in 2004 the centroid of each plot was visited by foot using a GPS.

\section{Cartography}

The field-verified land use and vegetation maps were assembled in a geographic information system built specifically for the PNCP using ArcView's ArcMap 9.2 (Esri, 1999) and the data layers were combined with coverage publicly available from the Comisión Nacional para el Conocimiento y Uso de la Biodiversidad (Conabio, 2010) such as access roads, urban and rural localities.

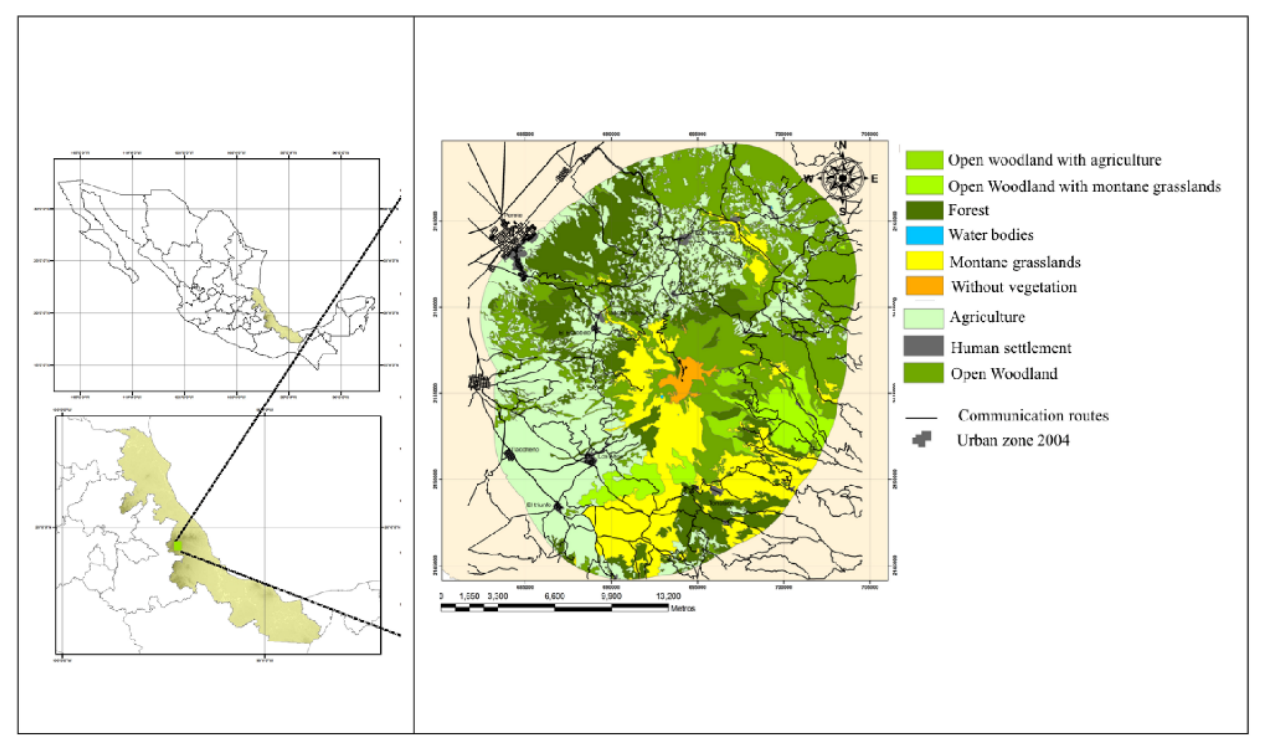

Figure 1. Land use and land cover at Mexicós Parque Nacional Cofre de Perote and the ejido El Conejo, 2004. 


\section{Data analysis}

Change in land use and land cover between 1995-2004 was done by crossing overlapping attribute tables using ArcMap's 'Union' function. Maps, data tables and a transition table were generated using the 'Dynamic Tables' in Excel v. 12.3.6 (Microsoft Corporation, 2008), and the net land use change was determined by land use and vegetation type.

The data table resulting from this analysis was used to estimate the relative transition probability (the probability that a land use category changes to a different one, expressed in percentage), based on the typology proposed by González and Marey (2009) with slight modifications for this study.

\section{The micro-scale: change in land use at ejido El} Conejo

This settlement was founded in 1897 as a sawmill town and formally established as an ejido in 1934, three years before the national park. El Conejo (768 ha) is the only ejido completely nested inside the PNCP, and it represents the conflict of dual land tenure typical of most protected areas in Mexico. Families have individual agriculture or cattle-raising plots that cannot be sold or given awaybut can be inherited by their children-and large portions of the titled land remain in control of the general assembly that determines temporary or permanent uses. Since 1994, ejidos have been formally allowed to become private property, but large portions of Mexico, particularly in the south, still remain organized as such. A buffer of $200 \mathrm{~m}$ was added to the perimeter of the study area in El Conejo, since the activities of its people also take place there, and document the results of a total of 1046 ha (Fig. 1).

\section{Interpretation of orthophotos to determine vegetation and land use}

Digital orthophotos were used at a scale of 1:75 000, pixel size $2 \mathrm{~m}^{2}$; line E14B26E (UTM projection, Spheroid GRS 80 , zone 14, datum ITRF92 in meters, March 1995) to determine vegetation type and land use (Inegi, 1995b).
Polygons were plotted to differentiate land cover categories and digitized them directly on the screen from the orthophoto background. Polygons were digitized at a 1:10 000 scale to diminish estimation errors (representation of true scale is 1:15 000). The minimum area size that was able to plot was approximately $3 \mathrm{~mm} \times 3 \mathrm{~mm}$, which means that only areas $900 \mathrm{~m}^{2}$ and larger are included in this map. Polygons were named or labeled by dominating land cover type, for example, a polygon labeled as 'Agriculture' had to contain more than $95 \%$ of its area with agricultural fields. Some features, such as areas with isolated trees that covered an area of $10 \%$ or less, were included in the category that dominated the remaining area. Some polygons that are labeled in mixed categories, such as 'open woodlands with vegetation' had to have between $60 \%-90 \%$ of its total area with the mix of agriculture and woodlands covering most of the polygons.

To generate the vegetation and land cover map for 2004, Inegi's (2004b) digital orthophotos were used at a 1:40 000 scale and a pixel size of $1 \mathrm{~m}^{2}$ (lines E14B26E3, E14B26E4, November 2004). The same steps were followed to generate both the 1995 and the 2004 maps.

\section{Change in land use and vegetation}

At both scales, the changes between 1995 and 2004 were estimated by a simple comparison of the data from both periods. Both maps were converted to a 1:15 000 scale and compared to other layers such as hydrology, roads, etc., of the 1:50 000 topographic map E14B26 for Perote. The standards and specifications set forth were followed by the Norma Oficial Mexicana NOM023-RECNAT-2001, Mexico's national standard to produce official inventories of land use at scales 1:20 000 and higher (Diario Oficial de la Federación, 2001). This national standard in turn follows the conventions of other countries such as the Netherlands and the United States. Also, ArcView 3.2 was used to process these maps (Esri, 1999).

The probability of change was estimated using a transition matrix model (McAuliffe, 1988): 


$$
A=\left[a_{i j}\right]=\sum_{j=1}^{n} a_{i j}
$$

Where $A$ is the transition between land use categories, and $a_{\mathrm{ij}}$ is the probability of change of category $i$ for category $j$ over time. The transition probabilities were calculated using the following equation:

$$
\begin{gathered}
r_{i j}=\frac{a_{i j}}{a_{i}} \\
i=1,2, \ldots, m ; j=1,2, \ldots, n
\end{gathered}
$$

Where $r_{\mathrm{ij}}$ is the probability of transition from category $i$ to category $j$ over time.

Although land cover and land use categories roughly correspond at both scales, the resolution of source data at both scales is different, so the categorization at both scales is not identical.

\section{RESULTS}

\section{Land use and land cover at the PNCP 1995-2004}

The first result is that the PNCP total area is 11530.70 ha, nearly 170 ha smaller than reported in official data. In 1995, the four most important land use categories (comprising $94 \%$ of the area of this national park) were agriculture, open woodland, open woodland with montane grassland and forest. By 2005, the four most important categories were agriculture, open woodland, forest, and montane grassland, totaling $89.9 \%$ of the total area (Fig. 2).

The most striking difference during this period was the change in open woodlands, which had a decadal loss of more than $80 \%$ of its initial area. In turn, the most remarkable increase was in montane grasslands, which had a nearly 10 -fold increase in one decade (these two changes correspond almost to the hectare with one another). Two other land use categories that had significant proportional changes (although small in total area, as none of them is over $160 \mathrm{ha}$ ) are open woodlands with agriculture and water bodies that increased about 1.3 times from its original cover.

The breakdown of gains and losses by categories, and the proportion of the total area that had no change are of great interest. Below the changes by category are shown (ranked by total area, from largest to smallest; Table 1). Most categories of land use remained relatively constant and the total areas and proportion of the total land cover had very few changes (Fig. 2).

Table 1. Land cover change by land use category (per hectare, ranked by total area) at the Parque Nacional Cofre de Perote, Mexico, 1995-2004.

\begin{tabular}{ccccc}
\hline Land use category & 1995 & 2004 & $\begin{array}{c}\text { Decadal } \\
\text { gain/loss }\left(\mathrm{ha}^{-1}\right)\end{array}$ & \% Change \\
\hline Agriculture & 3301.5 & 3208.2 & -93.3 & -2.8 \\
Open woodland & 2943.1 & 2804.2 & -138.9 & -4.7 \\
Fpen woodland with montane grassland & 2431.3 & 434.3 & -1997.0 & -82.1 \\
Forest & 2135.8 & 2220.5 & +84.7 & +3.9 \\
Without vegetation & 305.2 & 381.9 & +76.7 & +25.1 \\
Montane grassland (zacatonal) & 224.5 & 2129.1 & +1904.6 & +848.3 \\
Open woodland with agriculture & 113.2 & 272.8 & +159.6 & +140.9 \\
Human settlement & 75.3 & 75.3 & 0.0 & 0.0 \\
Water body & 1.9 & 4.3 & +2.4 & +126.3 \\
\hline
\end{tabular}




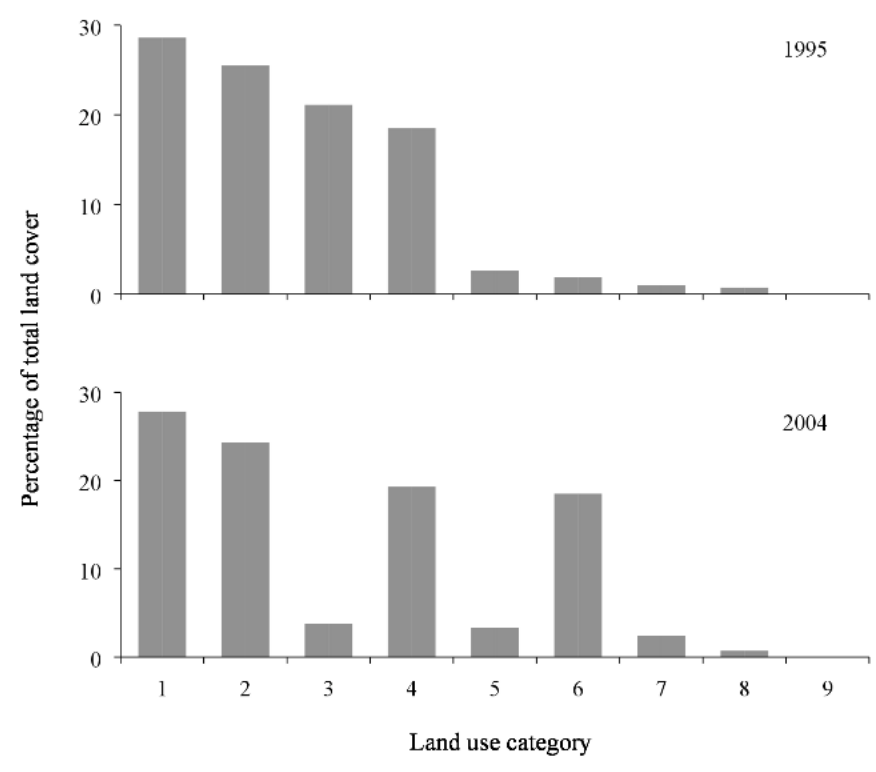

Figure 2. Land cover of the Parque Nacional Cofre de Perote 1995-2004.

Land use categories are: (1) agriculture, (2) open woodland, (3) open woodland with montane grassland, (4) forest, (5) without vegetation, (6) montane grassland, (7) open woodland with agriculture, (8) human settlement and (9) water body.

\section{Agriculture}

The majority of the area with this land use category remained unchanged. Agricultural areas were transformed into open woodland with agriculture, open woodland and forest.

\section{Open woodlands}

Like agriculture, most of this land use remained unchanged and kept its initial use. The small area that was transformed into other categories transitioned into forest, and very small areas changed into open woodland with montane grasslands, agriculture, montane grasslands and open woodlands with agriculture.

\section{Open woodlands with montane grasslands}

With the largest loss in total area, this land use was reduced to less than a sixth of its original cover. The majority of this area was transformed into montane grasslands.
Forest

This land use category had a small net gain. Although the small variation in total area seems to indicate this land use category had few changes, about a third of the initial area covered by forest shifted to another land use. The gains in forest area offset this forest loss come from successional progressions of open woodlands, open woodlands with montane grasslands and agriculture, which became forests during this decade.

\section{Without vegetation}

Areas that were devoid of vegetation in 1995 remained without it during the whole decade of this study. Areas without vegetation were formerly areas covered by open forest and agriculture.

\section{Montane grasslands}

This land use had the most striking gain in area, an almost ten-fold increase. It took over open woodland with montane grassland and open woodland. Eliminating sparsely distributed trees in the former land use is possibly the easiest land use transformation in this landscape.

\section{Open woodland with agriculture}

This land use more than doubled its initial cover. About a quarter of the area in the open woodland with agriculture class remained in this class. Gains in this class resulted from conversion from the open woodlands with montane grasslands class.

\section{Human settlements}

No change between 1995 and 2004.

\section{Water bodies}

Water bodies more than doubled its area in the decade of this study, taking over areas of woodland and montane grassland.

The probability of land use change $\left(r_{\mathrm{ij}}\right)$ at the PNCP in the 1995-2004 decade is estimated in table 2 . The three land use categories that had the highest probability of keeping the same land use over the ten years of this study 
are agriculture, open woodland with montane grassland and open woodland, the three most abundant categories that make up three quarters of the total area. In contrast, the most dynamic land use transformation probabilities are montane grasslands to open woodland with montane grasslands, open woodland with agriculture to agriculture, and forest to open woodland. The mean probability of land use categories keeping their current cover is 0.67 ( $\mathrm{SD}=0.37, \mathrm{n}=8$ ), whereas the mean probability of land use categories changing to a different cover is 0.04 ( $\mathrm{SD}=$ $0.14, \mathrm{n}=56)$.

\section{Land use and land cover at ejido El Conejo 1995- 2004}

Over $95 \%$ of ejido El Conejo is dominated by three land uses: agriculture (potato plantations), forest (dominated by sacred fir), and open woodland with agriculture. This ejido has a surprisingly static pattern of land use since its foundation: except for agriculture, the two major land use categories remained the same in the decadal period 1995-2004. The largest percentage change was recorded in one of the minor land use categories (shrubland) that actually represents less than $2 \%$ of the ejido area. Shrubland, one of the original vegetation types of the region dominated by the shrub Baccharis conferta, had actual area gains (Table 3).

\section{Agriculture}

The area dedicated to agriculture had a modest decrease over the decade of our study. Although agriculture has been, along with forestry, one of the two main activities of its people and it is striking that it hasn't gained additional area.

\section{Forest}

This land use had a negligible increase in area, less than $1 \%$, during the decade of this study. The forest remaining in the area is composed of patches of sacred fir, although this species is also present in the shrubland areas.

\section{Open woodland with agriculture}

The third most important land use category had a modest decrease.

\section{Human settlement}

This land cover increased by almost a third. Although modest in net area, this is also one of the most important changes recorded in the ejido.

Table 2. Matrix of transition probabilities of land use change at the Parque Nacional Cofre de Perote, Mexico, 1995-2004. Probability that a row probability will become a column category. Bold = probability of keeping its current land use.

\begin{tabular}{|c|c|c|c|c|c|c|c|c|}
\hline & Agriculture & $\begin{array}{l}\text { Human } \\
\text { settlement }\end{array}$ & $\begin{array}{c}\text { Open } \\
\text { woodland }\end{array}$ & $\begin{array}{l}\text { Open woodland } \\
\text { with agriculture }\end{array}$ & $\begin{array}{c}\text { Open woodland } \\
\text { with montane } \\
\text { grassland }\end{array}$ & Forest & $\begin{array}{l}\text { Montane } \\
\text { grassland } \\
\text { (zacatonal) }\end{array}$ & $\begin{array}{c}\text { Without } \\
\text { vegetation }\end{array}$ \\
\hline Agriculture & 0.97 & 0.00 & 0.01 & 0.02 & 0.00 & 0.00 & 0.00 & 0.00 \\
\hline Human settlement & 0.00 & 1.00 & 0.00 & 0.00 & 0.00 & 0.00 & 0.00 & 0.00 \\
\hline Open woodland & 0.01 & 0.00 & 0.75 & 0.00 & 0.01 & 0.22 & 0.01 & 0.00 \\
\hline $\begin{array}{l}\text { Open woodland with } \\
\text { agriculture }\end{array}$ & 0.40 & 0.00 & 0.50 & 0.10 & 0.00 & 0.00 & 0.00 & 0.00 \\
\hline $\begin{array}{l}\text { Open woodland with } \\
\text { montane grassland }\end{array}$ & 0.00 & 0.00 & 0.00 & 0.00 & 0.97 & 0.00 & 0.03 & 0.00 \\
\hline Forest & 0.02 & 0.00 & 0.26 & 0.00 & 0.04 & 0.68 & 0.00 & 0.00 \\
\hline Montane grassland & 0.00 & 0.00 & 0.03 & 0.00 & 0.88 & 0.00 & 0.09 & 0.00 \\
\hline Without vegetation & 0.01 & 0.00 & 0.19 & 0.00 & 0.00 & 0.00 & 0.00 & 0.80 \\
\hline
\end{tabular}


TABLE 3. Land cover change by land use category (in hectares, ranked by total area) at ejido El Conejo, PNCP, 1995-2004.

\begin{tabular}{ccccc}
\hline Land use category & 1995 & 2004 & Decadal gain/loss $\left(\mathrm{ha}^{-1}\right)$ & \% Change \\
\hline Agriculture & 400.23 & 280.70 & -119.53 & -29.86 \\
Forest & 367.03 & 369.70 & +2.67 & +0.72 \\
Open woodland with agriculture & 233.78 & 279.10 & +45.32 & +19.38 \\
Without vegetation & 20.18 & 1.76 & -18.42 & -91.27 \\
Human settlement & 15.71 & 20.85 & +5.14 & +32.43 \\
Shrubland & 14.13 & 25.76 & +11.63 & +82.30 \\
Shrubland with montane grassland & 13.45 & 0 & -13.45 & -100.00 \\
Shrubland with trees & 0 & 17.24 & -17.24 & + (gain) \\
\hline
\end{tabular}

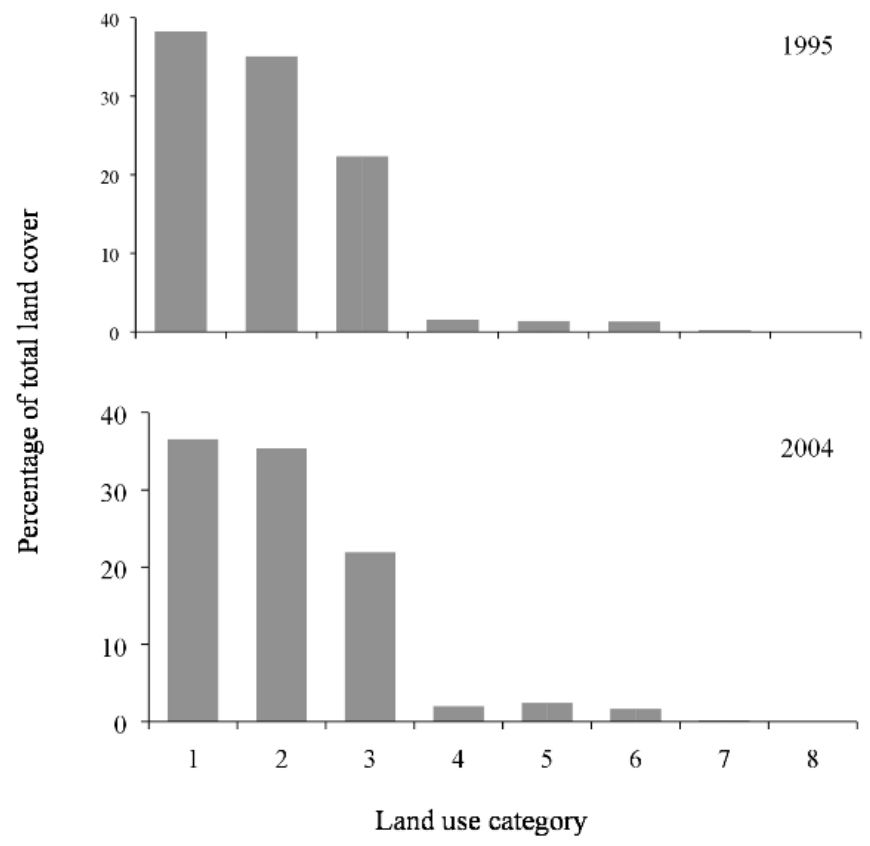

Figure 3. Land cover of El Conejo 1995-2004.

Land use categories are: (1) agriculture, (2) forest, (3) open woodland with agriculture, (4) human settlement, (5) shrubland, (6) shrubland with montane grassland, (7) without vegetation, and (8) shrubland with trees.

\section{Shrubland}

With the largest gain in total area, the advance of shrublands represents the progression of secondary succession in areas dedicated to other land uses.

\section{Shrubland with montane grassland}

The small area dedicated to this land use at the beginning of this study was completely gone in 2004 .

\section{Without vegetation}

The small patch of land with no vegetation recorded in 1995 essentially disappeared a decade later.

The probabilities of change $\left(r_{\mathrm{ij}}\right)$ of the seven land cover categories at El Conejo are shown in table 4. The mean probability of the different land cover categories keeping their current land use at the ejido is 0.69 (SD = $0.38, \mathrm{n}=7$ ), essentially the same documented for the PNCP as a whole, whereas the mean probability of change to a different land use is 0.03 ( $\mathrm{SD}=0.15, \mathrm{n}=42$ ), also in concordance with the one recorded for the broader national park.

\section{DISCUSSION}

\section{Land cover and land use trends}

The decadal dynamics of land cover and land use for the PNCP and El Conejo are very similar. At the larger, mesoscale, the most significant changes were the loss of a substantial amount of open woodlands and its replacement with montane grasslands. The shifts from one land use to another provide key information into the main drivers of habitat losses and gains-for the PNCP, the 
Table 4. Matrix of transition probabilities of land use change at ejido El Conejo, 1995-2004. Probability that a row will become a column category.

\begin{tabular}{cccccccc}
\hline & Agriculture & Forest & $\begin{array}{c}\text { Open woodland } \\
\text { with agriculture }\end{array}$ & $\begin{array}{c}\text { Human } \\
\text { settlement }\end{array}$ & Shrubland & $\begin{array}{c}\text { Shrubland with } \\
\text { montane grassland }\end{array}$ & $\begin{array}{c}\text { Without } \\
\text { vegetation }\end{array}$ \\
\hline Agriculture & 0.94 & 0.04 & 0.00 & 0.01 & 0.01 & 0.00 & 0.00 \\
Forest & 0.02 & 0.92 & 0.01 & 0.00 & 0.00 & 0.05 & 0.00 \\
$\begin{array}{c}\text { Open woodland with } \\
\text { agriculture }\end{array}$ & 0.00 & 0.04 & 0.95 & 0.00 & 0.01 & 0.00 & 0.00 \\
$\begin{array}{c}\text { Human settlement } \\
\text { Shrubland }\end{array}$ & 0.00 & 0.00 & 0.00 & 1.00 & 0.00 & 0.00 & 0.00 \\
Shrubland with mon- \\
tane grassland
\end{tabular}

Bold = probability of keeping its current land use.

main finding is the slow process of degradation of forests that are turned into woodlands and then into montane grasslands-. Cattle raising and agriculture are the two that stand out.

At the micro-scale, the ejido had no abrupt changes of substantial areas (Fig. 3), and the probability of change matrices at both scales have very similar trends as well (Tables 1 and 3). The method for estimating land cover and land use through the analysis of digital orthophotos, originally devised by González and Marey (2009), was successfully used in this case study.

The protected area of the PNCP has been severely affected by human activities like agriculture and cattle raising. Although most of the loss of natural land cover at the PNCP happened in a period much before the decade of this study, a large proportion of it happened after it became protected (García Romero, Montoya, Ibarra and Garza, 2010). This is by no means a situation exclusive of the PNCP: when comparing our statistics with those of other national parks such as the PN Pico de Tancítaro in the state of Michoacán (Sánchez, Bocco, Fuentes and Velázquez, 2003), a similar trend of loss of open woodlands and forests can be found.

\section{The role of the PNCP protecting sacred fir forests}

Vegetation type-wise, sacred fir forests in Mexico face a similar fate in many protected areas containing it. Sacred fir is widespread and it is the second land cover category in the study (Comisión Nacional de Áreas Protegidas [Conanp], 2011). Abies religiosa forests are present contiguously in temperate sub-humid areas of the Central Volcanic Belt, where the PNCP is located (Sánchez-González et al., 2005). Although this forest type is legally protected in five national parks, it faces serious problems inside all of these areas: illegal logging, loss and degradation of its functionality due to increases in agriculture, livestock grazing (bovines and sheep), human settlements and other causes. 


\section{What the meso and micro-scale trends tell us about effectiveness of management}

At the ejido, micro-scale, the management practices and dynamics of land use reflect those of the national park, meaning that its people can take good care of the protection of resources therein. This ejido, located inside the national park, also reflects a situation ubiquitous of Mexican national parks: the conflict of land tenure rights (in this case, for example, the establishment of the ejido precedes the declaration of the national park).

This situation can be turned into an opportunity. The ejido has a strong potential for being an ally of the national park for the management, and Mexico is internationally recognized for its work in community management of natural resources inside temperate zone national parks as well as sacred fir forests (Bray and Merino-Pérez, 2003, 2004; Bray, Durán-Medina, Merino-Pérez, Torres and Velázquez, 2007; Bray, Merino-Pérez and Barry, 2007; Madrid, Núñez, Quiroz and Rodríguez, 2009).

One key premise of these management models is that they are based on social organizations (Durán-Medina, Mas and Velázquez, 2007). In this case, it is possible to implement the management and recovery of the sacred fir forests through the strengthening of the existing social organization of El Conejo. Many initiatives focused on protecting and managing forests have failed for its excessive focus on enforcing tools that ignore the role of communities within or surrounding parks (Hansen, Spies, Swanson and Omán, 1991; Velásquez, Bocco and Torres, 2001; Bray et al., 2007b; Madrid et al., 2009; Larson et al., 2010).

\section{Management of national parks in Mexico when ejidos are present within their boundaries}

Ejidos and communities established within parks face difficulties in taking on management initiatives. For example, it is illegal for them to work on management plans for their natural resources because they are located inside a park. However, in practice, they actively use these forests without a plan and slowly degrade its forests through small-impact actions such as selective timber extraction and "ocoteo" (the subtraction of resin-saturated wood from the core of conifer trees without cutting the tree itself, a common resource for starting kitchen fireplaces).

National authorities are aware of conflicts like these, and the Conanp, the federal government agency in charge of managing national parks, recently issued an evaluation document defining the issues, objectives and strategies to improve the conservation of natural protected areas in the country, analyzing the effectiveness and impacts of its public policies (Conanp, undated).

These policies make no distinction of natural protected area categories and establish benchmarks to evaluate its success, many of them related to land tenure and gaining additional areas for conservation. Conanp's focus on land tenure, however, doesn't address the problem of clarifying and defining the relationship of people with legal land rights inhabiting protected areas.

This is a critical issue, because it does not recognize the rights of people legally inhabiting parks nor recognizes them as fundamental actors in its management and conservation. At the local scale, it is of core importance that the PNCP addresses this issue by incorporating social organizations from ejido El Conejo-and the people of all 13 localities of four municipalities related to the parkinto the management plans for this park.

\section{CONCLUSIONS}

Comparing the dynamics of land use at two different scales allowed this study to demonstrate the effectiveness of two management approaches and its effects in land use stability in this national park. In the decade of the study, the ejido management practices stabilized the dynamics of land use more effectively than those of the authorities charged with the protection of the park. This case study supports a growing body of evidence that shows that, given certain conditions, people living in protected areas can be effective stewards of its resources.

The results of the analysis allows to make a broader statement about the role of communities living inside national parks. For the state of Veracruz-and for Mexi- 
co's park system as a whole-the PNCP is an important natural protected area. Its protection requires rethinking its conservation strategies and management tools. This national park, like many other protected areas in the country, harbors important human settlements whose needs should to be integrated into the conservation vision of the park-that could guarantee the long-term stability of land cover and land use.

The PNCP, as well as five other national parks in the country, is essential for the protection of Mexico's Sacred fir forests. This vegetation type's restricted distribution has diminished its area to diverse set of causes, such as illegal logging, cattle ranching, new human settlements, etc.

The process of natural secondary succession from shrubland to forest could be used to increase forest cover. Gains in vegetation cover can help recover the ecological function, Carbon storage and other services associated with forests in good condition.

\section{REFERENCES}

Bocco, G., Mendoza, M. and Masera, O. R. (2001). La dinámica del cambio del uso del suelo en Michoacán. Una propuesta metodológica para el estudio de los procesos de deforestación. Investigaciones Geográficas, 44, 18-38.

Bray, D. B. and Merino-Pérez, L. (2003). A case study of El Balcón Ejido, Guerrero. In T. A. Wise, H. Salazar, L. Carlsen (Eds.), Confronting globalization: economic integration and popular response in Mexico (pp. 65-80). Bloomsfield, United States: Kumarian Press.

Bray, D. B. and Merino-Pérez, L. (2004). La experiencia de las comunidades forestales en México: Veinticinco años de silvicultura y construcción de empresas forestales comunitarias. Mexico City, Mexico: Instituto Nacional de Ecología.

Bray, D. B., Durán-Medina, E., Merino-Pérez, L., Torres R., J. M. and Velázquez M., A. (2007a). Nueva evidencia: los bosques comunitarios de México protegen el ambiente, disminuyen la pobreza y promueven la paz social. México City, Mexico: Universidad Nacional Autónoma de México, Instituto Politécnico Nacional, Florida International University, and Consejo Civil Mexicano para la Agricultura Sostenible Research Report.
Bray, D. B., Merino-Pérez, L. and Barry, D. (2007b). Los bosques comunitarios de México: Manejo sustentable de paisajes forestales. Mexico City, Mexico: Instituto Nacional de Ecología.

Consejo Civil Mexicano para la Silvicultura Sostenible [CCMSS]. (2009). Retos y oportunidades del sector forestal ante el cambio climático. Retrieved from http:// www.ccmss.org. $\mathrm{mx} /$ documentacion/230-nota-info23-retos-y-oportunidades-del-sector-forestal-ante-elcambio-climatico/

Collinge, S. K. (1996). Ecological consequences of habitat fragmentation: implications for landscape architecture and planning. Landscape and Urban Planning, 36, 59-77. doi: 10.1016/S0169-2046(96)00341-6

Comisión Nacional para el Conocimiento y Uso de la Biodiversidad [Conabio] (2010). Portal de georreferenciación. Sistema Nacional de Información Sobre Biodiversidad. Mexico City, Mexico: Comisión Nacional para el Conocimiento y Uso de la Biodiversidad. Retrieved from http:// www.conabio.gob.mx/informacion/gis/

Comisión Nacional de Áreas Naturales Protegidas [Conanp]. (2011). Programa de conservación y manejo Parque Nacional Cofre de Perote. Mexico City, México: Comisión Nacional de Áreas Naturales Protegidas.

Comisión Nacional de Áreas Protegidas [Conanp] (Undated document). Revisión y evaluación de medio término sobre la ejecución del Programa Nacional de Áreas Naturales Protegidas 2007-2012. Mexico City, Mexico: Comisión Nacional de Áreas Protegidas, Secretaría de Medio Ambiente, Recursos Naturales y Pesca.

Diario Oficial de la Federación. (2001). Norma Oficial Mexicana NOM-023-RECNAT-2001, Establece las especificaciones técnicas que deberá contener la cartografía y la clasificación para la elaboración de los inventarios de suelos. Mexico City, Mexico: Diario Oficial de la Federación, Gobierno Federal.

Durán-Medina, E., Mas, J. F. and Velázquez, A. (2007). Cambios en las coberturas de vegetación y usos del suelo en regiones con manejo forestal comunitario y áreas naturales protegidas de México. In D. B. Bray, L. Merino Pérez and D. Barry (Eds.), Los bosques comunitarios de 
México: Manejo sustentable de paisajes forestales (pp. 267-299). Mexico City, Mexico: Secretaría de Medio Ambiente, Recursos Naturales y Pesca, Instituto Nacional de Ecología, Consejo Civil Mexicano para la Silvicultura Sostenible. Instituto de Geografía de la Universidad Nacional Autónoma de México and Florida International Institute.

Ellis, E. and Pontius, R. (2007). Land-use and land-cover change. Encyclopedia of Earth. Washington, DC, United States: Environmental Information Coalition, National Council for Science and the Environment. Retrieved from http://www.eoearth.org/view/article/51cbee4f7896bb431 f696e92/

Environmental Systems Research Institute, Inc. [ESRI]. (1999). ArcView GIS Ver. 3.2. Redlands, United States: Environmental Systems Research Institute, Inc.

Food and Agriculture Organization of the United Nations [FAO]. (2016) Global Forest Resources Assessment 2015. How are the world's forests changing? (2nd ed.). Rome, Italia: Food and Agriculture Organization of the United Nations.

Geist, H. J. and Lambin, E. F. (2001). What drives tropical deforestation? A meta-analysis of proximate and underlying causes of deforestation base on subnational case study evidence. Louvain-la-Neuve, Belgium: Landuse and Cover-change.

García-Romero, A., Montoya, Y., Ibarra, M. V. and Garza, G. G. (2010). Economía y política en la evolución contemporánea de los usos del suelo y la deforestación en México: el caso del volcán Cofre de Perote. Interciencia, 35, 321328.

Gerez, P. and Pineda-López, M. R. (2011). Los bosques de Veracruz en el contexto de una estrategia estatal REDD+. Madera y Bosques, 17, 7-27.

Ghosh, P. (2004). Forest fragmentation: A threat to global biodiversity. ENVIS Bulletin on Himalayan Ecology, 12, 17-26.

González, X. P. and Marey, M. F. (2009). Fotointerpretación de los usos del suelo. Universidad de Santiago de Compostela. Retrieved from http://www.cartesia.org/data/apuntes/ fotointerpretacion/articulo_fotointerpretacion_metacortex.pdf
Graham, R. and Read, R. E. (1990). Manual de fotografía aérea. Barcelona, España: Omega.

Hansen, A. J., Spies, T. A., Swanson, F. J. and Omán, J. L. (1991). Conserving biodiversity in managed forests: Lessons from natural forests. Bioscience, 41, 382-392. doi: $10.2307 / 1311745$

Hobbs, R. J. (1993). Effects of landscape fragmentation on ecosystem processes in the Western Australian wheatbelt. Biological Conservation, 64, 193-201. doi: 10.1016/00063207(93)90321-Q

Instituto Nacional de Estadística, Geografía e Informática [Inegi]. (1995a). Ortofotos digitales 1:20,000 E14B26, E14B27, E14B36 y E14B37. Mexico City, Mexico: Instituto Nacional de Geografía y Estadística.

Instituto Nacional de Estadística, Geografía e Informática [Inegi]. (1995b). Ortofotos digitales 1:75.000 E14B26E. Mexico City, Mexico: Instituto Nacional de Geografía y Estadística.

Instituto Nacional de EstadísticaEstadística, Geografía e Informática [Inegi]. (2004a). Ortofotos digitales 1:20.000 E14B26, E14B27, E14B36 y E14B37. Mexico City, Mexico: Instituto Nacional de Geografía y Estadística.

Instituto Nacional de EstadísticaEstadística, Geografía e Informática [Inegi]. (2004b). Ortofotos digitales 1:40.000 E14B26E3 y E14B26E4. Mexico City, Mexico: Instituto Nacional de Geografía y Estadística.

Lambin, E. F. (1997). Modeling and monitoring land-cover change processes in tropical regions. Progress in Physical Geography, 21, 375-393. doi: 10.1177/030913339702100303

Larson, M. A., Corbera, E., Cronkleton, P., Van Dam, C. H., Bray, D., Estrada, M., May, P., Medina, G., Navarro, G. and Pacheco, P. (2010). Rights to forests and carbon under REDD+ initiatives in Latin America. CIFOR Infobrief, $33,1-8$.

Lee, H., Carr, J. L. and Lankerani, A. (1995). Human disturbance and natural habitat: a biome level analysis of a global data set. Biodiversity and Conservation, 4, 128-155. doi: 10.1007/BF00137781

Madrid, L., Núñez, J. M., Quiroz, G. and Rodríguez, Y. (2009). La propiedad social forestal en México. Investigación Ambiental, Sección Investigación, 1, 179-196. 
McAuliffe, J. R. (1988). Markovian dynamics of simple and complex desert plant communities. The American Naturalist, 131, 459-490. doi: 10.1086/284802

Masera, O. R. (1996). Deforestación y degradación forestal en México. Documentos de Trabajo No. 19. Pátzcuaro, Mexico: Grupo Interdisciplinario de Tecnología Rural Apropiada.

Microsoft Corporation, Inc. (2008). Microsoft Excel (2008). Redmond, United States: Microsoft Corporation.

Organisation for Economic Co-operation and Development [OECD]. (2003). Evaluación del Desempeño Ambiental. Mexico City, Mexico: Organisation for Economic Cooperation and Development .

Sánchez, J., Bocco, G., Fuentes, J. and Velázquez, A. (2003). Análisis de cobertura y uso del terreno en el contexto de su dinámica espacio-temporal. In Velázquez, A., Torres, A. and Bocco, A. (Eds.), Las enseñanzas de San Juan: Investigación participativa para el manejo de recursos naturales. (pp. 1-95). Mexico City, Mexico: Instituto Nacional de Ecología, Secretaría de Medio Ambiente, Recursos Naturales y Pesca.

Sánchez-González, A., López-Mata, L. and Granados-Sánchez, D. (2005). Semejanza florística entre los bosques de Abies religiosa (HBK) Cham. \& Schltdl. de la Faja Volcánica Transmexicana. Investigaciones Geográficas, 56, 62-76.
Secretaría de Desarrollo Agropecuario, Rural y Pesca del Estado de Veracruz [Sedarpa] and Comisión Nacional Forestal [Conafor]. (2006). Plan Sectorial Forestal de Veracruz. Actualización 2006-2028. Xalapa, Mexico: Secretaría de Desarrollo Agropecuario, Rural y Pesca del Estado de Veracruz and Comisión Nacional Forestal.

Tabarelli, M., Cardoso da Silva, J. M. and Gascon, C. (2004). Forest fragmentation, synergisms and the impoverishment of neotropical forests. Biodiversity and Conservation, 13, 1419-1425. doi: 10.1023/B:BIOC.0000019398. 36045.1b

Velázquez, A., Bocco, G. and Torres, A. (2001). Turning scientific approaches into practical conservation actions: The case of comunidad indígena de Nuevo San Juan Parangaricutiro, Mexico. Environmental Management, 27, 655665. doi: 10.1007/s002670010177

Received: 13 January 2017.

Accepted: 10 July 2017.

This paper must be cited as:

Pineda-López, M. R., Ruelas I., E., Sánchez-Velásquez, L. R., Espinoza G., M. A., Rojo A., A. and Vásquez-Morales, S. G. (2017). Dynamics of land use and land cover in a Mexican national park. Madera y Bosques, 23(3), 87-99. doi: 10.21829/myb.2017.2331492 